\title{
The Impact of Climate Change on the Sugar Content of Grapes and the Sustainability of their Production in the Czech Republic
}

\author{
Miroslava Navrátilová $^{1}$, Markéta Beranová ${ }^{1, *}$, Lucie Severová $^{2}$, Karel Šrédl $^{2} \oplus$, Roman Svoboda ${ }^{2}(1)$ and \\ Josef Abrhám 1 \\ 1 Department of Trade and Finance, Faculty of Economics and Management, Czech University of Life Sciences \\ Prague, Kamýcká 129, 16500 Prague, Czech Republic; navratilovam@pef.czu.cz (M.N.); \\ abrhamj@pef.czu.cz (J.A.) \\ 2 Department of Economic Theories, Faculty of Economics and Management, Czech University of Life Sciences \\ Prague, Kamýcká 129, 16500 Prague, Czech Republic; severova@pef.czu.cz (L.S.); sredl@pef.czu.cz (K.Š.); \\ svobodar@pef.czu.cz (R.S.) \\ * Correspondence: mberanova@pef.czu.cz; Tel.: +420-224-384-365
}

Citation: Navrátilová, M.; Beranová, M.; Severová, L.; Šrédl, K.; Svoboda, R.; Abrhám, J. The Impact of Climate Change on the Sugar Content of Grapes and the Sustainability of their Production in the Czech Republic. Sustainability 2021, 13, 222. https:// doi.org/10.3390/su13010222

Received: 27 October 2020

Accepted: 24 December 2020

Published: 29 December 2020

Publisher's Note: MDPI stays neutral with regard to jurisdictional claims in published maps and institutional affiliations.

Copyright: () 2020 by the authors. Licensee MDPI, Basel, Switzerland. This article is an open access article distributed under the terms and conditions of the Creative Commons Attribution (CC BY) license (https: / / creativecommons.org / licenses/by/4.0/).

\begin{abstract}
The aim of the presented article is to evaluate the impact of climate change on the sugar content of grapes in the Czech Republic during the period 2000-2019 through selected indicators on the basis of available secondary sources. Attention is focused on the developments in both the main wine-growing regions of Moravia and Bohemia. In the field of viticulture and wine-growing, the sugar content of grapes, as a basic parameter for the classification of wines, plays an important role. In the Czech Republic, the average sugar content of grapes has had a constantly growing trend. This trend is evident both in the wine-growing region of Bohemia and in the wine-growing region of Moravia. The impact of climate change, especially the gradual increase of average temperatures in the growing season, cannot be overlooked. It greatly affects, among other things, the sugar content of grapes. Calculations according to the Huglin Index and the Winkler Index were used to determine the relationship between climate and sugar content. These indexes summarize the course of temperatures during the entire vegetation period into a single numerical value. The results show that both indexes describe the effect of air temperature on sugar content in both wine regions of the Czech Republic in a statistically significant way. The Huglin Index shows a higher correlation rate. The Winkler Index proved to be less suitable for both areas. Alternatively, the Winkler Index calculated for a shorter growing season was tested, which showed a higher degree of correlation with sugar content, approaching the significance of the Huglin Index.
\end{abstract}

Keywords: sugar content; Czech Republic; vines; wine; climate change; sustainability; Huglin Index

\section{Introduction}

Agriculture is one of the basic pillars of human existence and represents one of its first organized activities [1]. The role of agriculture in the national economy of individual states has changed over time, but its importance remains unchanged [2-4]. In economically developed countries, emphasis has been placed on multi-functional agriculture in recent decades [5,6]. In addition to the economic aspects, the environmental and social dimensions of the agricultural sector, i.e., the non-production function of agriculture, have also come to the fore [7]. For example, in this context, Alonso [8] points to the importance of agritourism as a new form of coexistence in the regional context of tourism, while maintaining ecologically appropriate and sustainable agricultural practices. The results of Mura and Klujcnikov's research [9] confirm the importance of income from rural tourism and agritourism as tools for diversifying farmers' business risks. The basic precondition for the sustainable economic development of all sectors is the efficient use of production factors [10]. 
This is very closely related to the issue of sustainable development, which was defined in the Brundtland report 1987 [11]. Serrano et al. [12] point out that with the publication of the Brundtland report, the term "sustainability" has become a unifying idea for all academic disciplines. Escoto et al. [13] emphasize the interdisciplinary nature of sustainability and the importance of its societal role in improving long-term quality of life by seeking harmonious relationships between economic growth, social development, and environmental protection. In the scientific literature, considerable attention has been paid to the topic of sustainability over the last decade [14]. In agriculture, sustainability includes obtaining healthy and quality food, conserving natural resources, and biodiversity [4]. In the food industry, this issue is widely discussed, especially in the context of Corporate Social Responsibility [14].

Until the beginning of the 20th century, the prevailing opinion among the professional public was that the climate was not subject to change. The change in the spectrum of opinions in relation to this issue was caused only by the rise in temperatures after 1880 [15]. Based on systematic climate monitoring, some long-term temperature fluctuations have been identified, which have been accompanied by significant biological and economic impacts [16-18]. According to van Leeuwen and Darriet [18], agriculture is highly dependent on climatic conditions during the growing season of crops, which thus significantly affects global crop production $[18,19]$. It should be noted that in Europe, temperatures rose by an average of $1.2^{\circ} \mathrm{C}$ during the 20th century, the average number of summer days doubled, and the average number of tropical days tripled [20]. Trends found in long-term meteorological measurements performed in the Czech Republic also show a significant increase in average air temperature and a significant increase in the occurrence of extremes [21]. An analysis of the stability and diversity of agricultural production in the Czech Republic over the last 75 years suggests that changes in climatic factors have led to an increase in the production of some agricultural crops [22]. Based on a study of climate fluctuations in the Czech lands during the last millennium, Brazdil [23] states that a growing temperature trend can be observed from the middle of the 19th century.

The biological indicators of climatic fluctuations also include vines, especially in the context of their geographical distribution, yields, and wine quality depending on the weather [8]. The same conclusions were reached by Bock et al. [15], who monitored the relationships between yields, grape sugar content, and temperature over two centuries (1805-2010) and, based on long-term trends, found that temperature increases have an effect on both the harvest volume and sugar content in grapes.

Vine-growing is influenced by many factors, the most important of which can be considered the highly specific demands of this plant on soil and climatic conditions [24,25]. The growing season of the vine is about 180 days, and, for its successful growth, it requires winter calm and a stable climate without major temperature fluctuations [26]. Long-term temperature increases in Europe, North America, and Australia have had a demonstrable effect on grape composition, as the sugar concentration increases and acidity decreases [27].

From a global perspective, the area of vineyards decreased in the period 2000-2010, and fluctuations can be observed in the last decade [28,29]. Since 2016, the area of vineyards appears to have stabilized at around 7.4 million ha [29]. In 2018, 51\% of the vineyard area was concentrated in five countries, namely Spain (13\%), China (12\%), France (11\%), Italy $(9 \%)$, and Turkey $(6 \%)$. The total world grape production in 2018 reached 77.8 million tons [28].

Worldwide wine production was characterized by large fluctuations in the first decade of this century. In the second decade, there were significant changes in the structure of the largest producer countries. This fact can be partly explained by the reform of the wine sector in the EU member states. The producer countries of the so-called New World-Argentina, Australia, Chile, South Africa and, last but not least, China-came to the fore [30,31]. The total world production of wine in 2019 is estimated at 260 million hl, which means a significant decrease (11.5\%) compared to 2018. However, it should be noted that in 2018, wine production was exceptionally high compared to previous years [29]. 
The aim of the presented article is to evaluate the impact of climate change on the sugar content of grapes in the Czech Republic during the period 2000-2019 through selected indicators on the basis of available secondary sources.

\section{Materials and Methods}

According to the recommendations of Hendl and Remr [32], three areas were taken into account in the elaboration of the theoretical basis, namely the theory on the given topic, similar empirical studies on the given topic, and methodological literature. Therefore, scientific articles, professional publications, and current statistical data from official sources were used to determine a suitable theoretical framework.

The analysis itself was based on a comparison of secondary data and documents, taking into account their identification price according to the criteria from Hendl [33].

These were mainly official documents-situation and prospective reports on vine and wine from individual years, issued by the Ministry of Agriculture of the Czech Republic [34], documents from the Association of Winemakers of the Czech Republic [35], and reports from the International Organization of Vine and Wine [28,29]. The values and information obtained were analyzed and processed in order to create a suitable basis for subsequent interpretation and evaluation.

The article also describes the development of sugar content of grapes in total for the whole Czech Republic during the years 2000-2019. In the next step, the observed fact was also addressed from the perspective of the separate wine-growing regions of Bohemia and Moravia from 2011 to 2019 (partial values are only available from 2011). A summary of the data on the sugar content of grapes in the period observed is presented, specifically the average sugar content of white and blue vine varieties for individual years. Absolute and relative frequencies were used in the descriptive statistics that was applied to represent the data in the form of graphs and tables [36]. The Shapiro-Wilk test was used for normality of residues [37]. Heteroscedasticity was examined by the Breusch-Pagan test [38].

\subsection{Viticulture and Wine-Growing Sector in the Czech Republic}

The Czech Republic is a state located in Central Europe and has no access to the sea. It is bordered by Germany, Austria, Slovakia, and Poland (see Figure 2). Tomsik and Zufan [39] consider viticulture and wine-growing in the Czech Republic to be strategic and emphasize that supporting them can positively affect production and employment in wine-growing regions. The development of these sectors contributes to the deepening of landscape culture, the emphasis on ecology and the sustainability factors, and the expansion of wine tourism. Svobodova, Veznik, and Kral [40] add that from a global perspective, vine-growing in the Czech Republic is not very significant, but, for some regions, it represents an important benefit for the local economy [40,41].

In the Czech Republic, vine-growing is spread over two main wine-growing regions, namely the wine-growing region of Bohemia and the wine-growing region of Moravia. From a geographical point of view, it is possible to observe (see Figure 1) different characteristics of individual regions [42]. In the wine-growing region of Moravia, vine-growing and wine production have a long tradition, mainly thanks to the long-term favorable climatic conditions and the exceptionally high-quality soil resources $[43,44]$. This wine-growing region is very homogeneous and consists of four wine-growing sub-regions, namely the Znojmo, Mikulov, Velké Pavlovice, and Slovácko wine-growing regions. The Moravian wine-growing region is concentrated mainly in the South Moravian Region, with the exception of the Slovácko wine-growing region, which also extends into the neighboring Zlín Region. In this wine-growing region are almost $96.0 \%$ of the areas of all vineyards that are registered in the Czech Republic. The wine-growing region of Bohemia consists of two wine-growing sub-regions-Litoměřice and Mělník. This region is characterized by a high degree of dispersion throughout the Czech Republic, as it extends to seven of a total 14 regions of the Czech Republic [34,35,41]. 


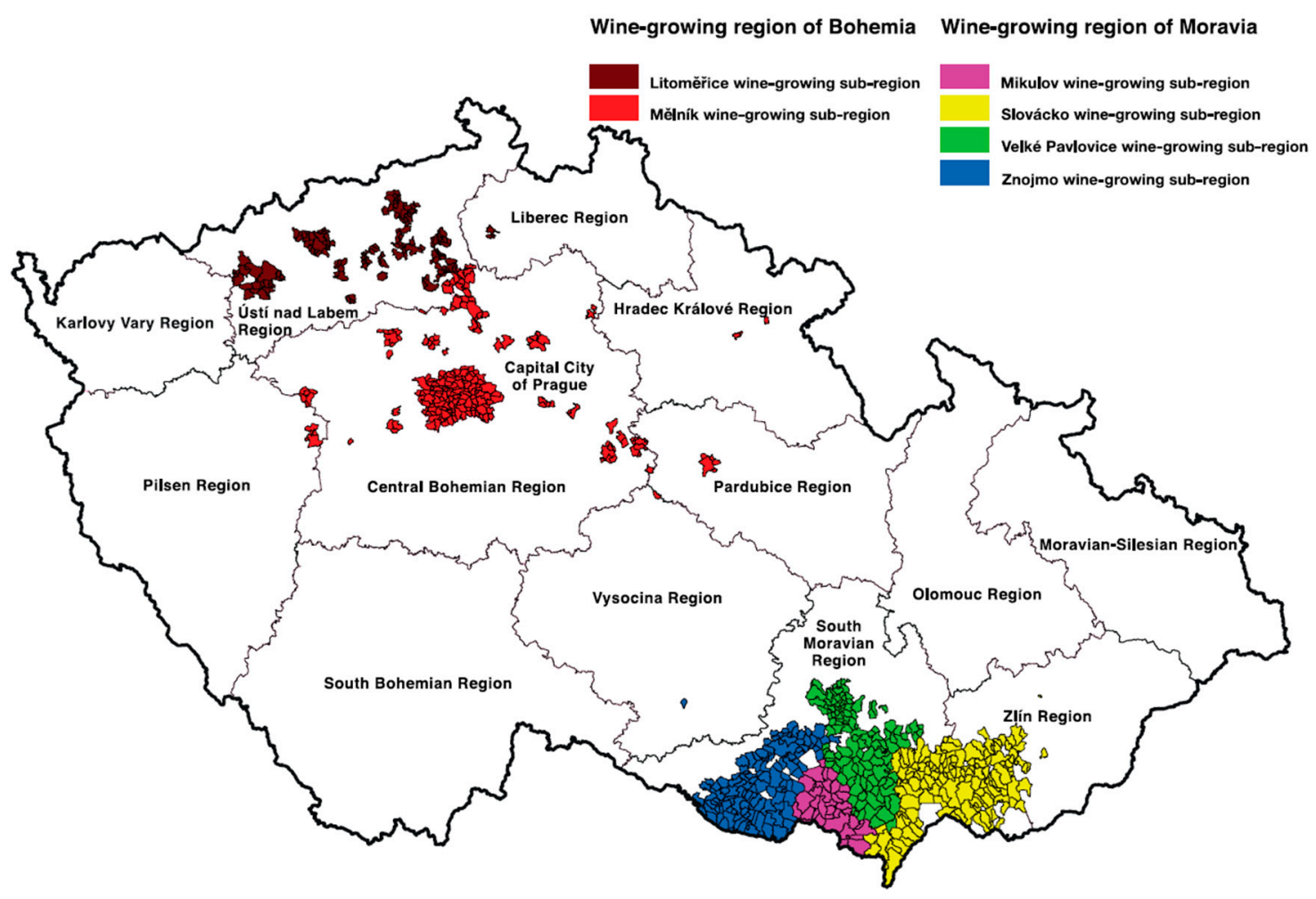

Figure 1. Wine-growing regions and sub-regions in the Czech Republic [42].

In 2018, the cultivated area of vineyards in the Czech Republic was approximately 18,068 ha, and the production potential in the Czech Republic reached the level of 600 ha more. As of 31 December 2018, 17,586 vine-growers were registered. In the period 20162018, wine production in the Czech Republic was around 645,000 hl/year. Of the total volume of wine produced, approximately two-thirds are white wines and one-third are red wines. In 2018, the import of wine products $(1,355,000 \mathrm{hl})$ clearly outweighed their export $(69,000 \mathrm{hl})$ [45].

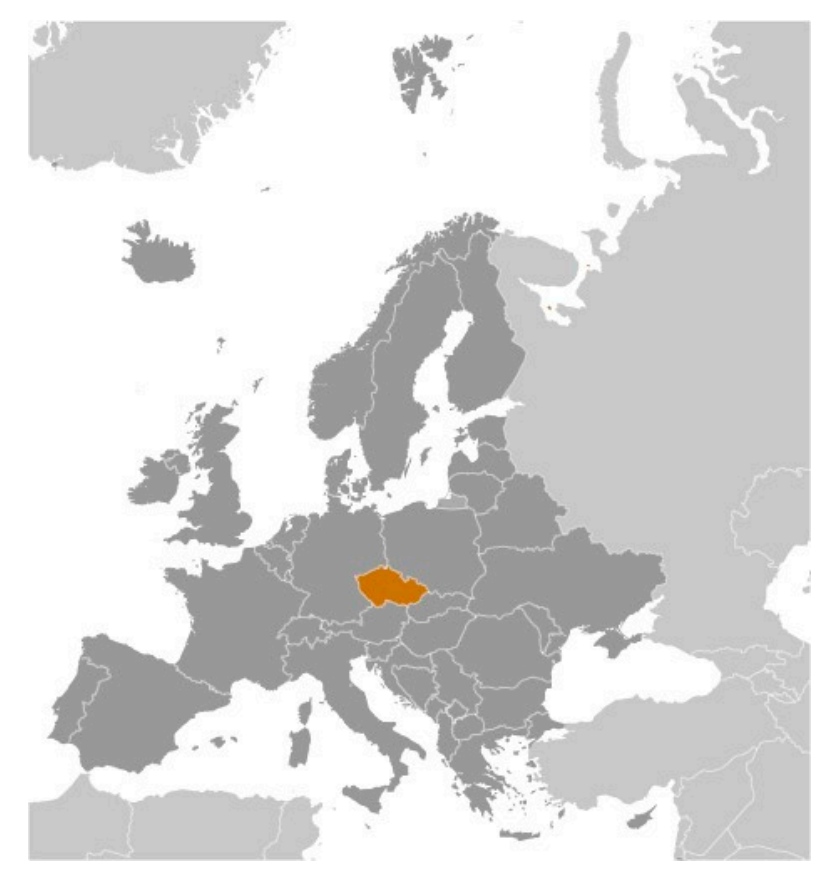

Figure 2. Location of the Czech Republic in the European perspective [46]. 
The total consumption of wine in the Czech Republic in the wine year 2018/2019 was 2.05 million hl [34]. The wine consumption per capita in 2018 was 20.41 per capita, which represents an increase of $10.3 \%$ compared to 2008 . On the other hand, a decrease of $7.3 \%$ in beer consumption can be observed in the years monitored $[47,48]$ despite the fact that it is an alcoholic beverage, which is traditional for the Czech Republic, both in terms of consumption and in terms of production. Based on the above values, it is possible to state changes in consumer preferences and behavior in the Czech Republic during the last decade.

\subsection{Sugar Content of Grapes and Labeling of Wines}

The sugar content of the grape must is the relative amount of sugar in the must before the fermentation process begins $[49,50]$. The density of the must is given in different units in different countries. The basis is usually an indirect density measurement. It can be a measurement of density based on Archimedes' law, a measurement of refractive index, a measurement of the twisting of the plane of polarized light, or other methods. Then, the measured sugar content is given either directly in units of quantity determined by the method or converted into one of the scales according to the relevant standard [49-51].

The mustmeter is used to measure the sugar content in the grape must. In the individual regions, standardized mustmeters have historically stabilized for measurement together with the methodology of their use. The result is values given in different units. For example, in France and the USA, the Baumé scale is used; in Germany, Switzerland, and Luxembourg, the Oechsle scale is used; and in Austria, the Klostenburg mustmeter is used [52-54]. In the Czech Republic and Slovakia, the standard mustmeter scale is most often used [55].

In Act No. 321/2004 Coll. on Viticulture and Wine-growing in the Czech Republic, the sugar content is defined as "the content of fermentable sugars in the grape must, expressed by a scale of a standard mustmeter". The scale of the standard mustmeter ( ${ }^{\circ} \mathrm{NM}$ ) (official in the Czech Republic (stupeň normalizovaného moštoměru) indicates the sugar content per $\mathrm{kg}$ unit per $100 \mathrm{~L}$ of must [55]. Pavlousek [56] adds that berries contain two basic fermentable sugars, namely fructose and glucose (at the time of ripeness and harvest, their ratio is 1:1), other sugars in berries and must are not fermentable, and their content is very low (raffinose, maltose, galactose, arabinose, and xylose). The measurement of sugar content is one of the elementary parameters important for the classification of wines into quality grades (see Table 1) because it determines the potential alcohol content in the future wine [57].

Table 1. Overview of the minimum sugar content of grapes for wine production and classification into a quality grade [55].

\begin{tabular}{ll}
\hline \multicolumn{1}{c}{ Wine Label } & \multicolumn{1}{c}{ Sugar Content } \\
\hline Regional wine & the grapes from which the wine was made have a sugar content of at least $14^{\circ} \mathrm{NM}$ \\
\hline Quality wine & the grapes from which the wine was made have a sugar content of at least $15^{\circ} \mathrm{NM}$ \\
\hline - with the attribute of cabinet wine & grapes with a sugar content of at least $19^{\circ} \mathrm{NM}$ \\
\hline - with the attribute of late harvest & grapes with a sugar content of at least $21^{\circ} \mathrm{NM}$ \\
\hline - with the attribute of selection of grapes & grapes with a sugar content of at least $24^{\circ} \mathrm{NM}$ \\
\hline - with the attribute of selection of berries & from selected berries that have reached a sugar content of at least $27^{\circ} \mathrm{NM}$ \\
\hline - with the attribute of selection of cibebas & $\begin{array}{l}\text { from selected berries infested with noble gray mold or from overripe berries which } \\
\text { have reached a sugar content of at least } 32^{\circ} \mathrm{NM}\end{array}$ \\
\hline - with the attribute of ice wine & $\begin{array}{l}\text { from grapes which were harvested at temperatures of minus } 7^{\circ} \mathrm{C} \text { and lower, which } \\
\text { remained frozen during harvesting and processing, and the must obtained has a sugar } \\
\text { content of at least } 27^{\circ} \mathrm{NM}\end{array}$ \\
\hline & $\begin{array}{l}\text { from grapes which have been stored on straw or reed before processing or have been } \\
\text { hung in a ventilated area for at least } 3 \text { months, and the must obtained has a sugar } \\
\text { content of at least } 27^{\circ} \mathrm{NM} \text {. However, if the must already has a sugar content of at least } \\
32^{\circ} \mathrm{NM} \text { after only } 2 \text { months, pressing may be carried out }\end{array}$ \\
\hline
\end{tabular}


Measuring the sugar content of grapes for wine production is the basis of the so-called Germanic method of wine labeling, which is based on quality classification. This way of labeling wine is currently prevalent in the Czech Republic. To compare the sugar content of grapes, Table 1 shows the minimum sugar content for the Germanic method of wine labeling, for which the sugar content of grapes is decisive.

Table 1 provides an overview of the quality grades of wine and the required sugar content for classification into a given group. The values of the minimum sugar content are set in Act No. 321/2004 Coll. on Viticulture and Wine-growing, in which it is stated that wine can be sweetened only in the manner prescribed by European Union regulations. Sweetening is prohibited for quality wines with an attribute [55].

Another way of labeling wine is the so-called Romanesque method, in which attention is focused on the place of origin of grapes or wine, i.e., territories of production. The territory from which the wine comes is an important indicator of wine quality assessment $[24,58]$.

In the Czech Republic, this method of wine labeling is represented by the certification "Wines of original certification". This certification is a form of cooperation between individual winegrowers and wineries that can help these organizations gain a competitive advantage on the wine market [58]. The system of such labeling has great potential in the Czech Republic, as it is based on tradition and makes it easier for consumers to find their way around individual wine quality parameters [59]. This method is also based on the mandatory requirements for the minimum sugar content of grapes for wine production for each stakeholder.

For the sake of completeness, it is necessary to distinguish the term residual sugar from the term sugar content. The sweetness in the already finished wine is caused by the residual sugar, i.e., the unfermented grape sugar, which remained after the end of the fermentation process $[60,61]$. An overview of the classification of wines by their residual sugar according to the International Organisation of Wine and Vine [62] is given in the following Table 2.

Table 2. Overview of the classification of wines by the residual sugar content [62].

\begin{tabular}{|c|c|}
\hline Wine Label & Sugar Content \\
\hline Dry wine & $\begin{array}{l}\text { has a sugar content of up to } 4 \mathrm{~g} / \mathrm{L} \text { but may have up to } 9 \mathrm{~g} / \mathrm{L} \text { if the overall difference between the sugar content } \\
\text { and the acid content is less than } 2 \mathrm{~g} / \mathrm{L}\end{array}$ \\
\hline Semi-dry wine & $\begin{array}{l}\text { has a sugar content that exceeds the sugar content for the label "dry" up to } 12 \mathrm{~g} / \mathrm{L} \text {, but it may have up to } \\
18 \mathrm{~g} / \mathrm{L} \text { if the overall difference between the sugar content and the acid content is higher than for the label "dry" }\end{array}$ \\
\hline Semi-sweet wine & if it has a sugar content that exceeds the sugar content for the label "semi-dry" and does not exceed $45 \mathrm{~g} / \mathrm{L}$ \\
\hline Sweet wine & if it has a sugar content of at least $45 / \mathrm{g} / \mathrm{L}$ \\
\hline
\end{tabular}

Data on residual sugar should be given on the label of the final product in accordance with Act No. 321/2004 Coll. on Viticulture and Wine-growing, always in accordance with binding terminology [55].

\subsection{Impact of Climate on Sugar Content of Grapes}

In order to simplify the global description of weather during the growing season, a number of indexes were established in the past that quantify the impact of weather by a single aggregate value. These indexes make it possible to make qualified estimates of the impact of climate change on the characteristics of the final agricultural product-here, wine.

These indexes are mainly based on the assumption that vegetation dormancy occurs at temperatures below $10^{\circ} \mathrm{C}$ and that the crop generally depends on the air temperature and the time for which the crop is exposed to this temperature. Some indexes also describe the humidity and the associated quality of the harvest or susceptibility to disease, or the impact of cold and frost. The indexes used include the Huglin Index, Winkler Index, Branas Heliothermic Index, Branas Hydrothermic Index, Bioclimatic Index, Dryness Index, 
Selyanin Hydrothermal Coefficient, Cool Night Index, and Continentality Index [63,64]. The Huglin Index, determined in France, is most often used for the quantification of the weather impact [65]. It is calculated as the sum for all days from April to September:

$$
H I=k \sum_{A p r 1}^{\text {Sept } 10} \frac{\left(t_{a v g}+t_{\max }-20\right)}{2}
$$

where

HI-Huglin Index

$t_{\text {avg }}$-average daily temperature

$t_{\max }$-maximum daily temperature

$k$-latitude constant (for $50^{\circ}$ north latitude, which also includes the Czech Republic, according to Huglin (1986) [65], this value is 1.06).

Another frequently used index is the Winkler Index [66]. It is very similar to the Huglin Index. The sum uses the minimum and maximum temperatures reduced by $10^{\circ} \mathrm{C}$ from the daily averages. Negative values are calculated as zero when addition is performed, and the growing period is calculated from April to October inclusive. The index was created in California, so its parameters (especially the length of the growing season) reflect the local conditions. It is used mainly in the USA, but it is used less in Europe [67].

$$
W I=\sum_{A p r 1}^{\text {Oct } 31} \max \left(\frac{\left(t_{\min }+t_{\max }-20\right)}{2}, 0\right)
$$

where:

WI-Winkler Index

$t_{\min }$-minimum daily temperature

$t_{\max }$-maximum daily temperature

Other indexes incorporate not only temperature but also other weather parameters. Within the framework of this article, only the two above-mentioned indexes and their suitability for the conditions of wine-growing regions of the Czech Republic are assessed. Data from the network of stations of the Czech Hydrometeorological Institute were used to assess the impact of climate [68]. Since the network is not specifically focused on winegrowing regions, some time lines are incomplete, and, in addition, some stations are located in places that are not indicative of the environment of vineyards (for example on mountain tops), only one typical station near the center of a given sub-region with a complete data line for the reference period was chosen for each of the six wine-growing sub-regions of the two wine-growing regions of the Czech Republic. The meteorological stations Brno-Turany, Kuchařovice, Strážnice, and Lednice were chosen for the Moravian region, and Doksany and Tuhaň were chosen for the Bohemian region [68].

The following abbreviations are used in the article: ${ }^{\circ} \mathrm{NM}=$ degrees of standardized mustmeter, EU = European Union, $\mathrm{P}-\mathrm{B}=$ Breusch-Pagan test, $\mathrm{S}-\mathrm{W}$ test $=$ Shapiro-Wilk test.

\section{Results}

In this section, the summarized results obtained are presented in two sub-sections. In the first part, attention is focused on the development of the sugar content of grapes in the Czech Republic, both in total and in individual wine-growing regions. The second part numerically and graphically presents the values obtained for the relationship between the Huglin Index, Winkler Index, and sugar content.

\subsection{Development of Sugar Content of Grapes in the Czech Republic}

In 2000, the situation in the wine-growing regions of Bohemia and Moravia was as follows. In the wine-growing region of Bohemia, the average yield was around $5.7 \mathrm{t} / \mathrm{ha}$, and the average sugar content of grapes was around $19.9^{\circ} \mathrm{NM}$. In the wine-growing region of Moravia, all wine-growing sub-regions were observed. The average yield of grapes 
here was around $6.2 \mathrm{t} / \mathrm{ha}$. The average sugar content of grapes was around $19.6^{\circ} \mathrm{NM}$. In 2000, the detected sugar content reached the highest values in the last 11 years [34]. The development of sugar content of grapes in the Czech Republic is clearly shown in the following graph (Figure 3).

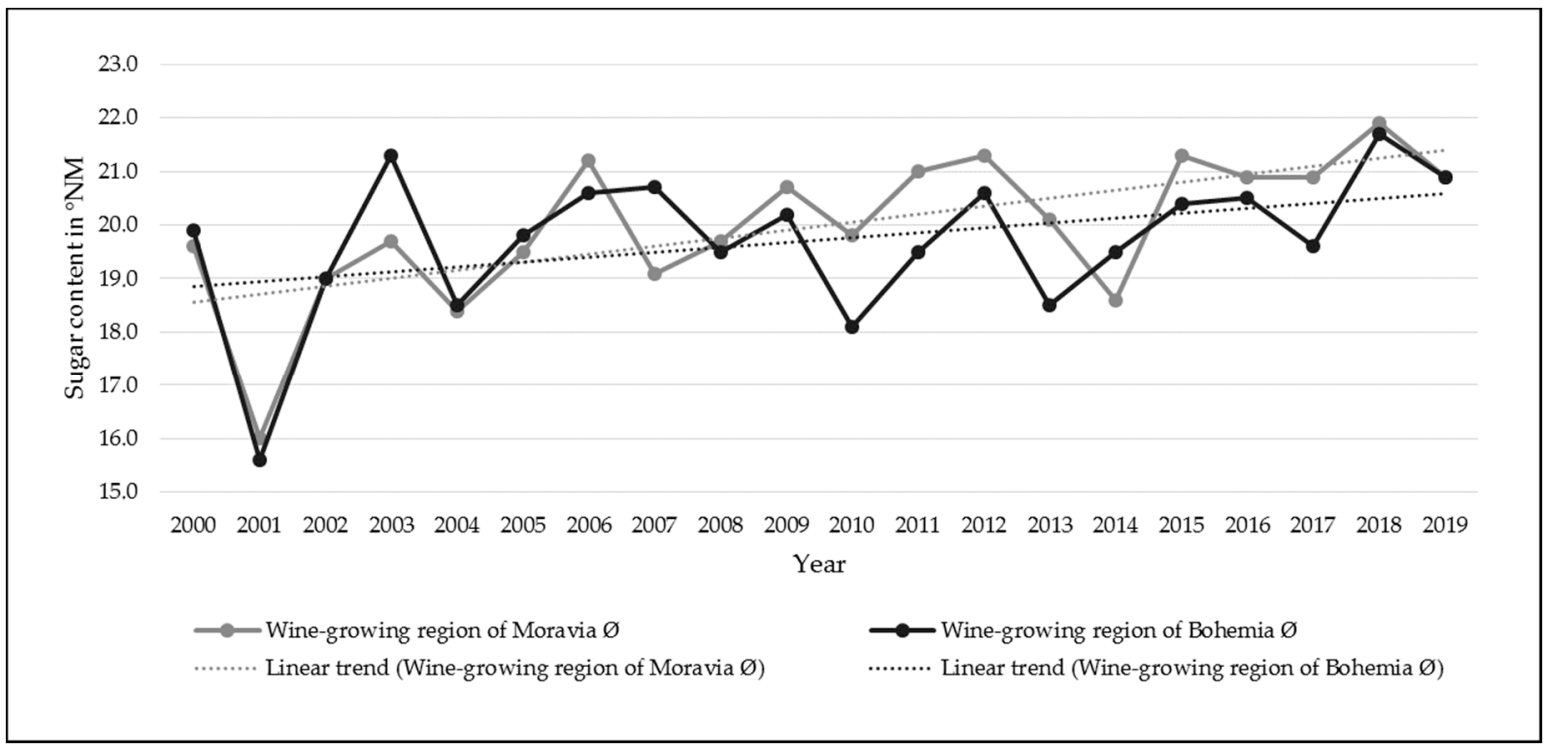

Figure 3. Development of the sugar content of grapes in the regions of Moravia and Bohemia during the years 2000-2019 (own elaboration according to [34]).

Figure 3 shows the trend of growth in sugar content over the last 20 years. In the last examined year, 2019, the average sugar content in the Bohemian wine-growing region was around $20.9^{\circ} \mathrm{NM}$ (as in the Moravian region). The average sugar content in the Moravian region was at the level of $20.9^{\circ} \mathrm{NM}\left(1.0^{\circ} \mathrm{NM}\right.$ lower than in the previous year and exactly at the level of the ten-year average). The average sugar content of grapes has been steadily increasing since the adoption of the Viticulture and Wine-growing Act by $4.6^{\circ} \mathrm{NM}$ on average over the last 24 years [34].

Figure 4 shows the sugar content of grapes in individual wine-growing regions of Bohemia and Moravia during the period 2011-2019; the minimum and maximum value of sugar content in the given region in the observed years is always given.

The figure (Figure 4) clearly shows a growing trend of sugar content in the period observed. This fact is mainly evident from the increasing maximum value of sugar content in the wine-growing region of Bohemia when, in 2011, the maximum value of sugar content reached $20.5^{\circ} \mathrm{NM}$, and, in 2019 , it was even $22.4^{\circ} \mathrm{NM}$, which indicates an increase in the maximum sugar content of grapes during the years observed by $1.9^{\circ} \mathrm{NM}$. In the same years, the Moravian wine-growing region showed a larger range in terms of the minimum and maximum of the observed values, but the difference between the two observed years was not so large. In 2011, the maximum value of the sugar content reached $24.9^{\circ} \mathrm{NM}$, and, in 2019 , it was even $26.0^{\circ} \mathrm{NM}$, so the increase in the maximum sugar content was $1.1^{\circ} \mathrm{NM}$. 


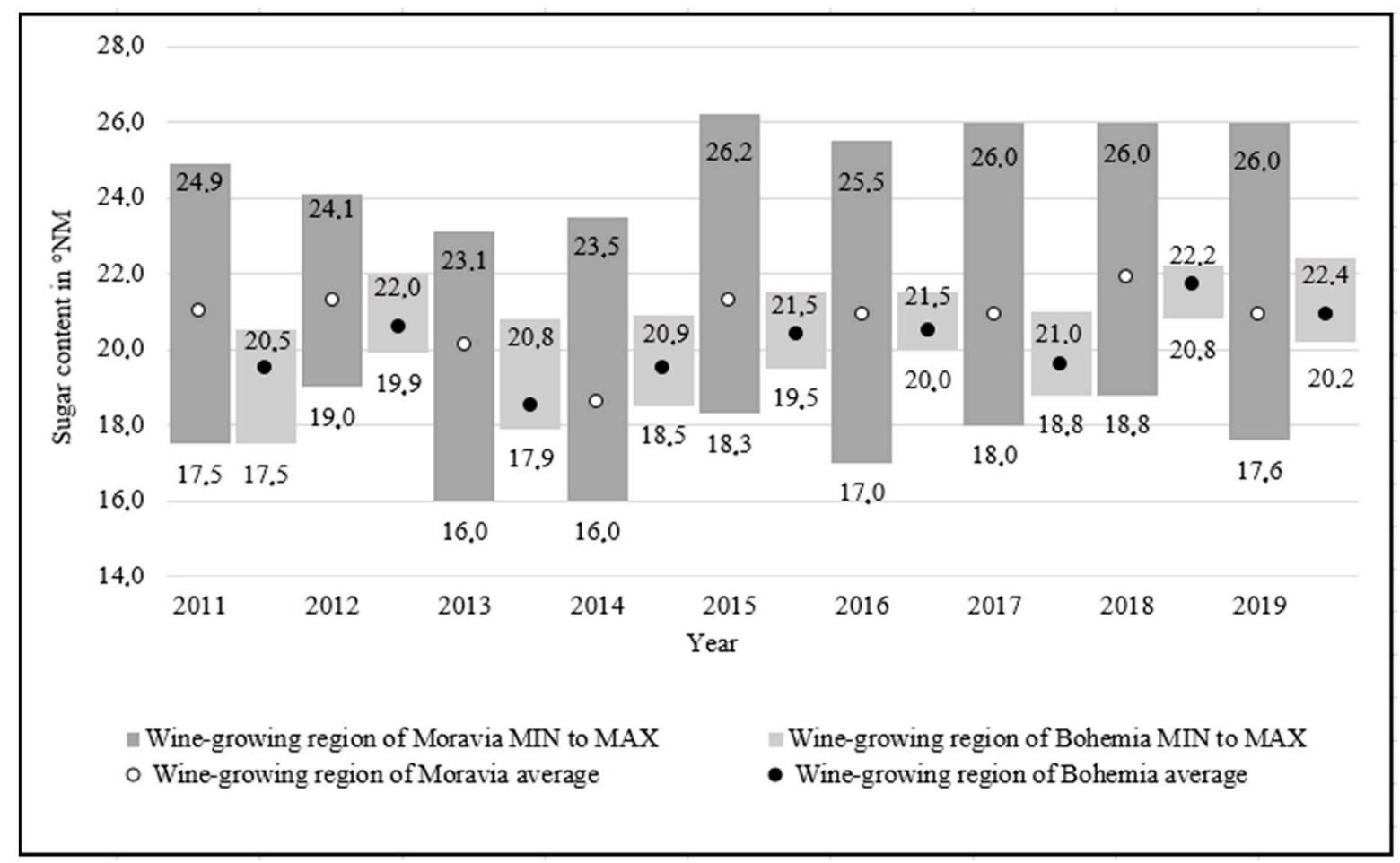

Figure 4. Development of sugar content of grapes in the wine-growing region of Bohemia and Moravia during the years 2011-2019 (own elaboration according to [34]).

\subsection{Application of Selected Indicators}

In order to determine the impact of climate change, it is necessary to verify the suitability of the climate index used for estimating the sugar content of wine. Therefore, the values of the indexes calculated from selected climatic data for the period from 20002019 and the sugar content of wines from harvests in the same period were compared. The Huglin and Winkler Indexes were selected for the comparison. The Winkler Index was first calculated in the period specified by the author and then recalculated for the period corresponding to the Huglin Index (marked "Winkler shortened"). The change was tested because the original index was, according to calculations, less indicative of the sugar content.

The residue normality of all models was not rejected $(\alpha=0.05)$ by the Saphiro-Wilk test for data from the wine-growing region of Bohemia. Heteroscedasticity was rejected $(\alpha=0.05)$ by the Breush-Pagan test. For the wine-growing region of Moravia, the data had to be adjusted by removing the years 2002, 2006, and 2014 due to the multiplication of residue values. The residue normality of the data was not rejected $(\alpha=0.05)$ and heteroscedasticity was rejected $(\alpha=0.05)$ by performing variation.

From the values of the correlation coefficients, it is clear that both the Huglin and Winkler coefficients in both variants sufficiently explain the sugar content of grape must from both wine-growing regions of the Czech Republic. In all cases, the $T$-test showed that the dependence was statistically significant. The correlation coefficients, expressing the degree of dependence, are higher in both regions for the Huglin Index than for the Winkler Index. Therefore, it is clear that the Huglin Index is more indicative of the relationship between climate and sugar content in the Czech Republic. The Winkler Index, calculated for a shorter period, indicates a lower dependence. For the wine-growing region of Moravia, the correlation coefficient is practically identical to the Huglin Index. This fact can be attributed to the excellent natural conditions for growing vines in a wine-growing area in the context of ripening and harvesting. 
The values from the tables (Tables 3 and 4) are further visualized in graphs (see Figures 5-7). The $x$-axis shows the value of the given index, and the $y$-axis shows the average sugar content.

Table 3. Selected indicators from 2000 to 2019, wine-growing region of Moravia (own elaboration according to $[34,68])$.

\begin{tabular}{ccccc}
\hline Year & ${ }^{\circ}$ NM & Huglin Index & Winkler Index & Winkler Index Shortened \\
\hline 2000 & 19.6 & 1944.8 & 1376.9 & 1276.3 \\
2001 & 16.0 & 1635.2 & 1197.0 & 1110.2 \\
2002 & 19.0 & 1849.5 & 1308.7 & 1294.4 \\
2003 & 19.7 & 2114.2 & 1466.4 & 1444.4 \\
2005 & 19.5 & 1738.2 & 1191.7 & 1147.1 \\
2006 & 21.2 & 1859.7 & 1338.1 & 1261.9 \\
2008 & 19.7 & 1841.4 & 1276.7 & 1236.9 \\
2009 & 20.7 & 2051.5 & 1436.7 & 1380.8 \\
2010 & 19.8 & 1692.9 & 1177.3 & 1168.1 \\
2011 & 21.0 & 1960.1 & 1380.3 & 1328.4 \\
2012 & 21.3 & 2038.9 & 1449.0 & 1401.7 \\
2013 & 20.1 & 1774.8 & 1290.0 & 1242.8 \\
2015 & 21.3 & 2038.0 & 1438.0 & 1408.4 \\
2016 & 20.9 & 1958.2 & 1364.3 & 1337.7 \\
2017 & 20.9 & 1970.9 & 1419.4 & 1369.0 \\
2018 & 21.9 & 2377.9 & 1761.8 & 1679.4 \\
2019 & 20.9 & 2029.1 & 1486.7 & 1411.5 \\
Average & 20.1 & 1940.4 & 1373.6 & 1326.0 \\
Correlation Coefficient & 0.70 & 0.67 & 0.72 \\
$p$-value F-test & 0.01 & 0.001 & 0 \\
p-value T-test & 0.01 & 0.01 & 10.43 \\
y-intercept & 9.69 & 11.16 & 0.007278 \\
\multicolumn{2}{r}{ slope } & 0.005355 & 0.006499 & 0.01 \\
S-W test residuals $p$-value & 0.03 & 0.01 & 0.12 \\
B-P test residuals $p$-value & 0.07 & 0.17 & \\
\hline \multicolumn{5}{r}{}
\end{tabular}

Table 4. Selected indicators from 2000 to 2019, wine-growing region of Bohemia (own elaboration according to $[34,68])$.

\begin{tabular}{ccccc}
\hline Year & ${ }^{\circ}$ NM & Huglin Index & Winkler Index & Winkler Index Shortened \\
\hline 2000 & 19.9 & 1888.1 & 1337.6 & 1252.0 \\
2001 & 15.6 & 1601.3 & 1185.0 & 1098.8 \\
2002 & 19.0 & 1851.6 & 1309.0 & 1284.4 \\
2003 & 21.3 & 2059.0 & 1410.7 & 1391.7 \\
2004 & 18.5 & 1762.4 & 1146.9 & 1106.1 \\
2005 & 19.8 & 1788.8 & 1216.3 & 1159.3 \\
2006 & 20.6 & 1937.9 & 1372.2 & 1306.8 \\
2007 & 20.7 & 1911.0 & 1266.4 & 1240.5 \\
2008 & 19.5 & 1686.0 & 1136.4 & 1105.4 \\
2009 & 20.2 & 1911.9 & 1274.3 & 1230.7 \\
2010 & 18.1 & 1686.8 & 1144.9 & 127.6 \\
2011 & 19.5 & 1939.5 & 1332.0 & 1254.8 \\
2012 & 20.6 & 1911.2 & 1277.5 & 1155.0 \\
2013 & 18.5 & 1700.5 & 1202.8 & 1203.0 \\
2014 & 19.5 & 1838.8 & 1282.3 & 1276.8 \\
2015 & 20.4 & 1943.3 & 1303.3 & 1294.1 \\
2016 & 20.5 & 1950.0 & 1319.1 & 1221.2 \\
2017 & 19.6 & 1831.1 & 1285.1 & 1573.6 \\
2018 & 21.7 & 2390.1 & 1634.6 & 1303.2 \\
\hline 2019 & 20.9 & 1992.6 & 1357.1 & \\
\hline
\end{tabular}


Table 4. Cont.

\begin{tabular}{|c|c|c|c|c|}
\hline Year & ${ }^{\circ} \mathbf{N M}$ & Huglin Index & Winkler Index & Winkler Index Shortened \\
\hline Average & 19.7 & 1879.1 & 1289.7 & 1242.9 \\
\hline \multicolumn{2}{|c|}{ Correlation Coefficient } & 0.82 & 0.68 & 0.75 \\
\hline \multicolumn{2}{|c|}{$p$-value F-test } & 0 & 0.01 & 0 \\
\hline \multicolumn{2}{|c|}{$p$-value $T$-test } & 0 & 0.01 & 0 \\
\hline \multicolumn{2}{|c|}{$y$-intercept } & 7.33 & 9.09 & 8.41 \\
\hline \multicolumn{2}{|c|}{ slope } & 0.006591 & 0.008240 & 0.009100 \\
\hline \multicolumn{2}{|c|}{ S-W test residuals $p$-value } & 0.01 & 0.00 & 0.01 \\
\hline \multicolumn{2}{|c|}{$\mathrm{B}-\mathrm{P}$ test residuals $p$-value } & 0.44 & 0.35 & 0.25 \\
\hline
\end{tabular}

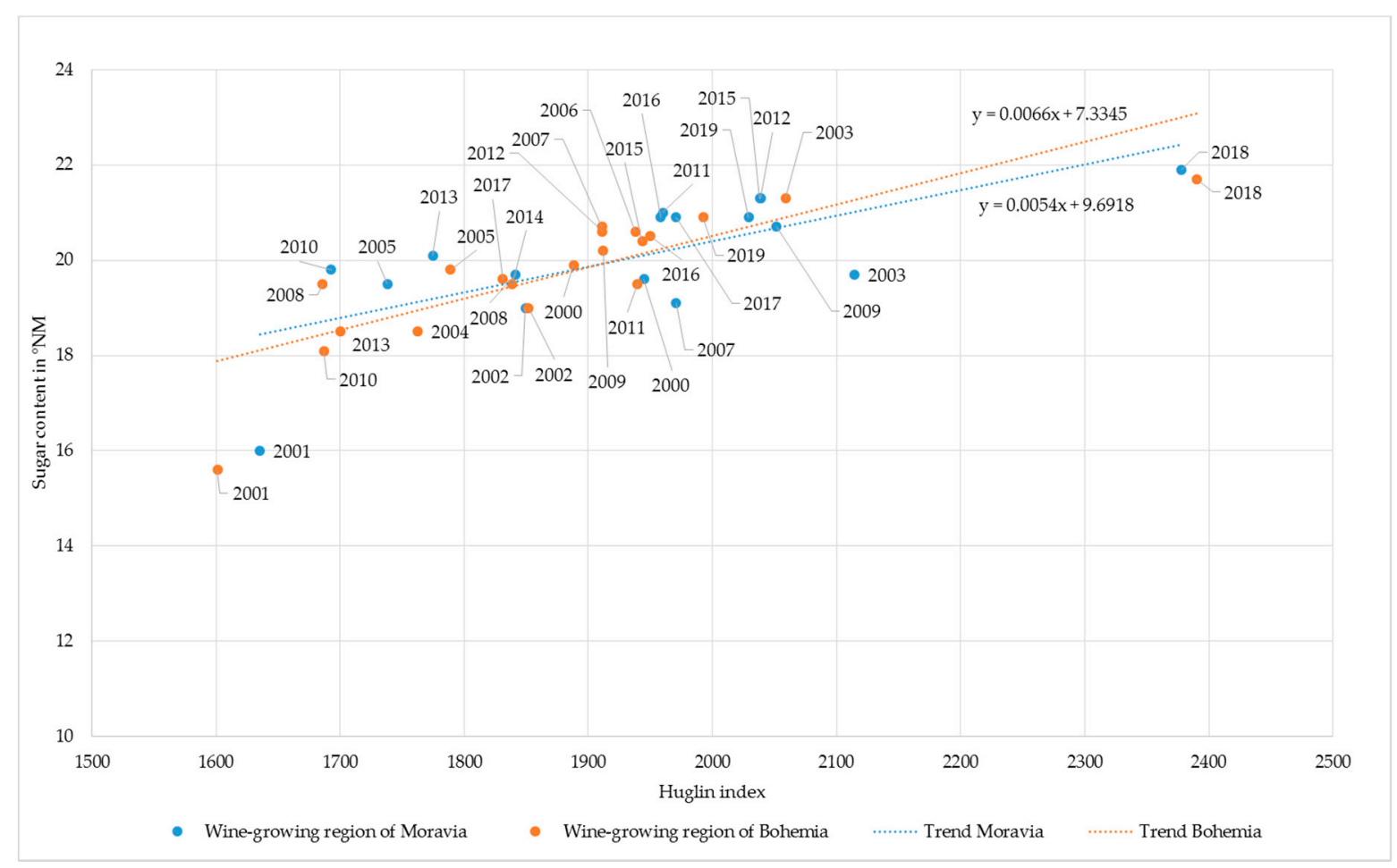

Figure 5. Relationship between Huglin Index and the sugar content of grapes in two wine-growing regions in the Czech Republic (own elaboration according to $[34,68]$ ).

Figure 5 shows the relationship between the Huglin Index and the sugar content of the must in the period 2000-2018 separately for the Bohemian region and the Moravian region. A statistically significant trend, also visible on the graph, shows that the Huglin Index is well suited to expressing the relationship between climate and sugar content. Only the atypically cold year 2001 deviates from the trend described by this index.

Figure 6 shows the same data explained by the Winkler Index. The description of sugar content using this index is less indicative, which is also reflected in the lower value of the correlation coefficient. For the cold year 2001, the Winkler coefficient gives too high a value, which does not correspond to the measured sugar content. This is mainly due to the fact that the level of the index is influenced by the weather after the harvest, which, of course, can no longer affect the sugar content. This is best seen in the cold year of 2001, where the warm autumn was reflected in the level of the index. Due to the fact that the Winkler Index in its original form does not correspond to the climatic conditions in the Czech Republic, the observed period was shortened. The results can be seen in the following graph (Figure 7). 


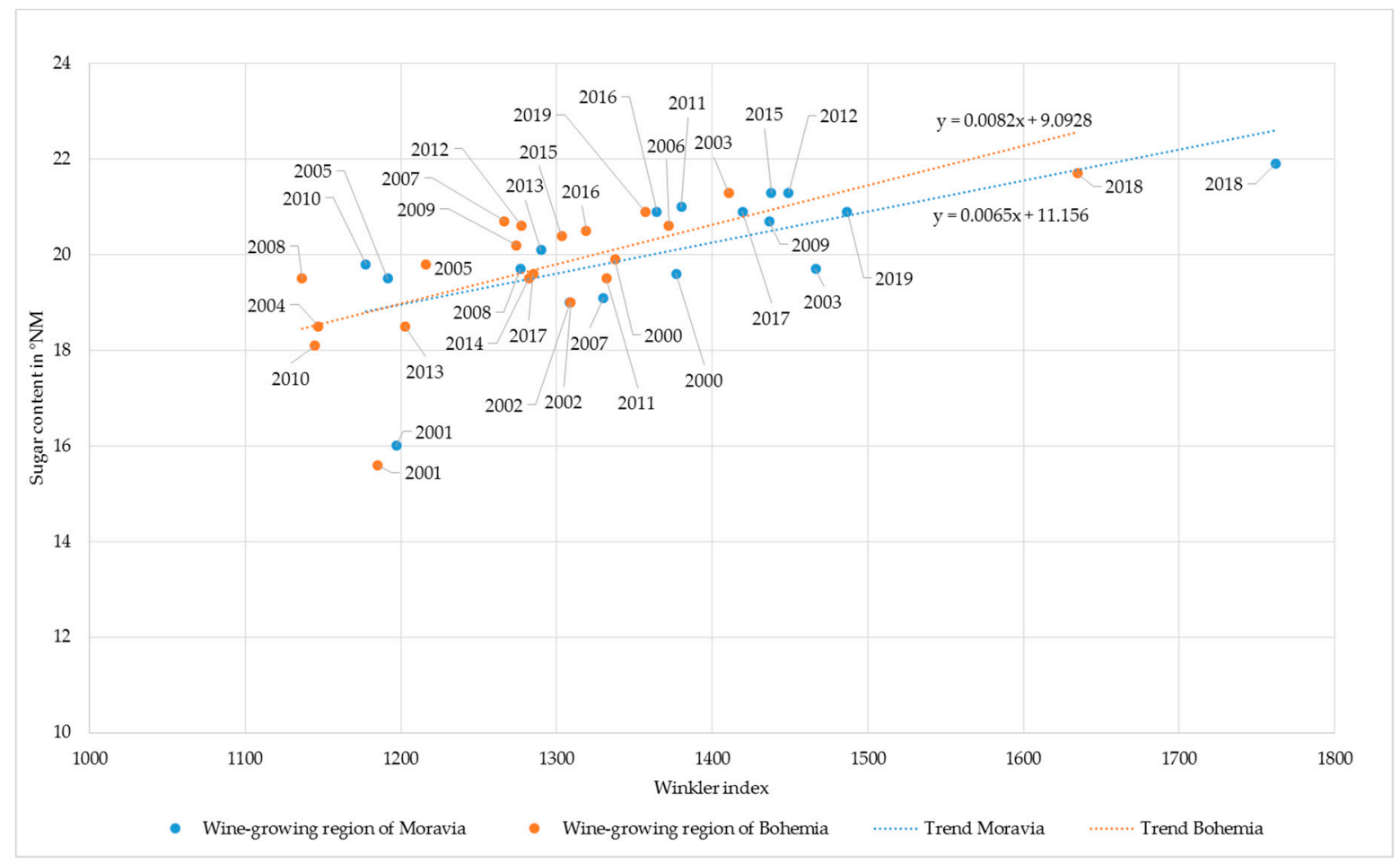

Figure 6. Relationship between Winkler Index and the sugar content of grapes in two wine-growing regions in the Czech Republic (own elaboration according to $[34,68]$ ).

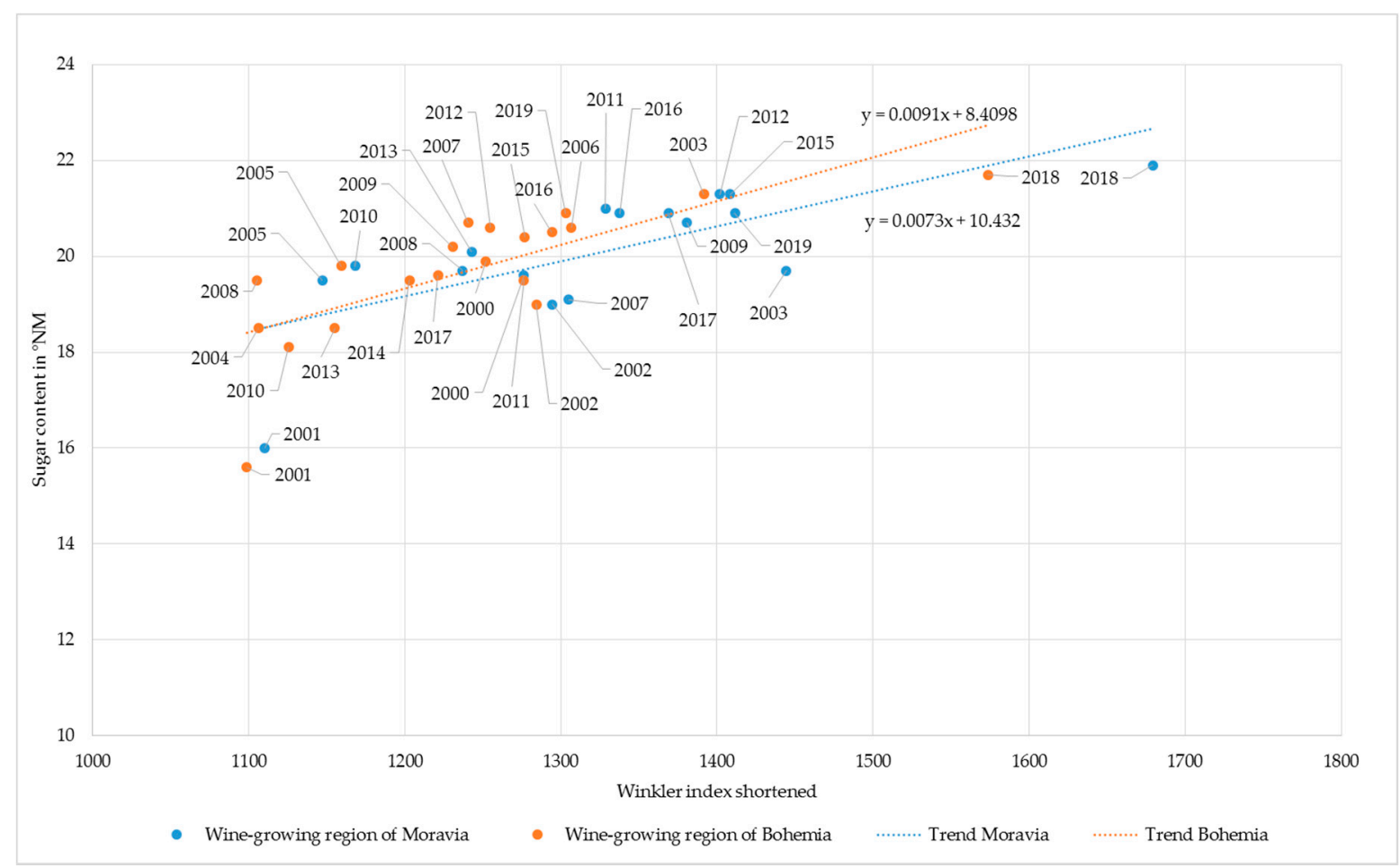

Figure 7. Relationship between Winkler Index (shortened) and the sugar content of grapes in two wine-growing regions in the Czech Republic (own elaboration according to [34,68]).

To make the Winkler Index more indicative, the period from which the index is calculated has been shortened by one month. Then, the period determined in this way is 
the same as for the Huglin Index and better describes the way wine is grown in Europe. This is also reflected in a greater correlation with sugar content.

From the graphs and the calculations above, it is clear that the Huglin Index is more indicative of the link between climatic data and sugar content in the observed areas.

The description by the Winkler Index gives better results in the shortened variant, but, even in this case, its link to sugar content is only slightly better for the wine-growing region of Moravia and worse for the wine-growing region of Bohemia.

\section{Discussion}

Climate change can significantly affect ecosystems in the agricultural landscape [69] and, of course, have significant environmental impacts on European agriculture and on the formulation of agricultural policy priorities in Europe [70]. This implies the need to find ways to predict the impacts of climate change on the conditions for growing crops so that measures can be implemented in practice to eliminate or reduce potential risks in the long term $[69,70]$.

One of the sectors that is very sensitive to climate change within the agrarian complex is viticulture and wine-growing, especially due to the high degree of dependence of vinegrowing on climatic and environmental conditions [71]. Therefore, climate change is crucial for wine production, as most wine-growing regions in the world are located in relatively narrow latitudinal bands with average temperatures of the growing season limited to $13-21{ }^{\circ} \mathrm{C}$ [72]. The knowledge gained in viticulture and wine-growing in the field of climate change can be practically used in other areas of agriculture [24,73].

As already mentioned, specific climatic conditions are crucial for achieving the complete ripening of the grape, and climate variability determines the year-on-year differences in the yield and the quality of the wine produced [74]. The research results of Blanco-Ward et al. [72] suggest a positive relationship between higher heat accumulation during the growing season and higher vine yields. Return on investment in wine production is determined by a set of factors such as selling price, quality and prestige, and the size of yields [25].

Temperature and sunlight are particularly critical variables because they have a direct effect on the length of the growing season, phenological phases, grape yields, and the synthesis and accumulation of sugars, organic acids, polyphenols, vitamins, and aromatic compounds in berries [75,76]. Climatic factors are summarized in a number of climatic indexes, from which the suitability of the Huglin and Winkler Indexes was verified on the basis of climatic data for the environment of the Czech Republic, the second of which was in the variant for a shortened period.

In the observed period of 20 years, the statistical analysis performed proved a good indicative power of the Huglin Index and both versions of the Winkler Index for the sugar content of must in wine-growing regions of the Czech Republic. In the Moravian region, the binding of all indexes to sugar content is similar (correlation coefficients $0.67-0.71$ ); in the Bohemian region, the Huglin Index (correlation coefficient 0.82) appears to be the best, followed by the shortened Winkler Index (correlation coefficient 0.75 ). Therefore, the Huglin Index is most suitable for the overall expression of the relationship between the climate and the sugar content of grapes in the Czech Republic.

The structure of both indexes (they are the sum of normalized daily temperatures for a fixed period) shows that an increase in the average temperature by $1{ }^{\circ} \mathrm{C}$ will cause an increase in the indexes by the number of days they include. For the Huglin Index, it is a value of 183, for the Winkler Index, it is a value of at most 214, and for the shortened Winkler Index, it is a value of at most 183 . The Winkler Index does not count the days below $10{ }^{\circ} \mathrm{C}$; thus, an increase in the temperature by $1{ }^{\circ} \mathrm{C}$ in colder locations may cause an increase by less than the number of days it includes. However, in practical use in the Czech Republic, this rare occurrence can be neglected.

Approximately 8000 vine varieties are currently known, indicating a wide genetic diversity of this plant; however, these are not currently used $[77,78]$. In most countries, only 
12 vine varieties are currently grown on $70-90 \%$ of the cultivated area of vineyards [79]. Wolkovich et al. [79] draw attention to the need to diversify the vine varieties cultivated in order to preserve the traditional wine-growing regions and their historical, cultural, and economic importance. Bigard et al. [80] equally emphasize the importance of the use of genetic diversity of vine varieties in cultivation programs as one of the possible ways to mitigate the adverse effects of global warming on viticulture [36]. This is also confirmed by Neethling et al. [81], based on their research conducted among French wine-makers. The results of their research showed that producers consider the establishment of appropriate short-term strategies, the change of cultivated vine varieties, and the issue of irrigation to be the most important [27].

Globally, the climate change in relation to vine-growing can be described as significant and key $[16,60]$, as the ripening time of the vine grapes has decreased in many geographical areas, and the composition of grapes has changed in recent years [82-84]. In the long run, these facts may affect the demand for wine and thus the overall economic situation in a particular region, as the origin of the grapes plays an important role in the perception of the quality and value of wine [24]. Wine consumers are also increasingly associating the quality of wine with its geographical origin and the sustainability of production, which includes the agronomic and ecological conditions and the reduction of the environmental impact of viticulture $[85,86]$. This fact is also confirmed by the findings of the ProWein organization [87], which conducted a questionnaire survey among the stakeholders in the wine industry. The results show that more than half of respondents (56\%) believe that in the future, consumers can be expected to prefer wines produced in a climate-neutral way.

Some authors agree [88-90] that in the future, it will be possible to assume the emergence of new wine-growing regions in localities where previously the cultivation of vines was not possible. In this context, Mosedale et al. [24] point out that when establishing vineyards in new localities in connection with climate change, it is also necessary to take into account potential risks such as negative impacts on ecosystems or the loss of biodiversity in the locality [15]. Increased use of water for irrigation and the cooling of grapes due to warming also appears to be potentially problematic for the conservation of freshwater resources. Then, new practices can cause conflicts in the field of soil protection and use [25].

For this reason, adaptation and mitigation measures are important for the future of the wine industry [71]. In this context, the need to adapt viticulture and wine-growing to the current situation can be considered the most important task of these sectors [60]. Some producers are aware of the current problems, and the stakeholders are seriously considering the sustainability of the current production model [84]. This is also confirmed by the current ProWein Business Report 2019 [87], which states that $86 \%$ of the wine industry players believe that the focus should be on improving the sustainability of production.

On the one hand, the sensory properties of wine are important; on the other hand, the marketing tools through which this product is presented also play an important role [89,90].

An increasing number of studies and research [91-94] from various parts of the world have confirmed that climate change has had a growing effect on the individual growth stages of grapes, their composition and, last but not least, their sensory aspects. Climate change has had many different effects on growing vines, especially on the sugar content of grapes, which has been addressed, for example, by Irimia et al. [95] from Romania. The results of their research lead to the conclusion that the sugar content in grapes correlates with climatic variables specific to vineyards with climatic suitability for wine production, which is in line with the conclusions of the authors of the presented article. The effect of climate on the quality of grapes has also been confirmed by other research from various wine-growing regions of the world [75,96-98].

\section{Conclusions}

Viticulture and wine-growing are a traditional part of the agri-food complex on a global scale. Successful vine-growing requires specific soil conditions and a stable climate without major temperature changes. Current climate changes mainly affect the sugar 
content in grapes and, thus, the quality of the final product-wine. The present article evaluates the impact of climate change on the sugar content of grapes in the Czech Republic during the period 2000-2019 using selected indicators-the Huglin Index and the Winkler Index. This issue is observed throughout the country, but specific attention is paid to the situation in the individual main wine-growing regions of Bohemia and Moravia. Secondary data, which were drawn from official sources, were used for the analysis of the sugar content itself. The results show that in the Czech Republic, the sugar content of grapes has increased over the years, which poses new challenges for the field of viticulture and wine-growing that must be faced. The theoretical benefit of the article is the presentation of the summarized information on the issue, while the practical benefit is the application of the shortened version of the Winkler Index, which was adapted to the climatic conditions of vine-growing in the Czech Republic. A relatively shorter observed period, limited by the fact that comprehensive information on the sugar content of grapes was not systematically observed in the previous period, can be considered a limiting factor of the article submitted. The authors consider an international comparison with countries with similar natural conditions for growing vines to be another possible direction of research. In future research, attention will also be paid to the geographical origin of wine as a final product, i.e., the labeling of wine according to the Romanesque method.

Author Contributions: Conceptualization, M.N. and M.B.; methodology, M.N. and M.B.; formal analysis, R.S., K.Š. and M.B.; investigation, M.N. and M.B.; resources, L.S.; data curation, M.N. and L.S.; writing—original draft preparation, M.N. and M.B.; writing—review and editing, L.S, K.Š., R.S. and J.A.; visualization, M.B. and R.S.; supervision, L.S.; project administration, K. Š. and R.S.; funding acquisition, L.S. All authors have read and agreed to the published version of the manuscript.

Funding: This work was funded by the Faculty of Economics and Management, Czech University of Life Sciences in Prague (Internal Grant Agency, IGA) under Grant number 2020B0002_-“The impact of climate change on the economic performance of the viticulture and wine-making sector in the Czech Republic".

Institutional Review Board Statement: Not applicable.

Informed Consent Statement: Not applicable.

Data Availability Statement: The individual data sources are listed in the source list.

Conflicts of Interest: The authors declare no conflict of interest.

\section{References}

1. Kjeldsen-Kragh, S. The Role of Agriculture in Economic Development: The Lessons of History, 1st ed.; Copenhagen Business School Press: Copenhagen, Denmark, 2007.

2. McArthur, J.W.; McCord, G.C. Fertilizing growth: Agricultural inputs and their effects in economic development. J. Dev. Econ. 2017, 127, 133-152. [CrossRef] [PubMed]

3. Pretty, J.; Benton, T.G.; Bharucha, Z.P.; Dicks, L.V.; Flora, C.B.; Godfray, H.C.J.; Goulson, D.; Hartley, S.; Lampkin, N.; Morris, C.; et al. Global assessment of agricultural system redesign for sustainable intensification. Nat. Sustain. 2018, 1, 441-446. [CrossRef]

4. Marunelu, I. Research on the Small Peasant Individual Households in Romania within the Framework of Sustainable Agriculture. Sci. Pap. Ser. Manag. Econ. Eng. Agric. Rural Dev. 2020, 20, 341-346.

5. Duvernoy, I.; Zambon, I.; Sateriano, A.; Salvati, L. Pictures from the other side of the fringe: Urban growth and peri-urban agriculture in a post-industrial city (Toulouse, France). J. Rural Stud. 2018, 57, 25-35. [CrossRef]

6. $\quad$ Renting, H.; Rossing, W.A.H.; Groot, J.C.J.; Van der Ploeg, J.D.; Laurent, C.; Perraud, D.; Stobbelaar, D.J.; Van Ittersum, M.K. Exploring multifunctional agriculture. A review of conceptual approaches and prospects for an integrative transitional framework. J. Environ. Manag. 2009, 90, S112-S123. [CrossRef] [PubMed]

7. Tvrdon, J. Conception of the model of agriculture with production and non-production function. Agric. Econ. 2003, 49, 208-212. [CrossRef]

8. Alonso, G.R. The Agrotourism, a vision from sustainable development. Cent. Agric. 2019, 46, $62-65$.

9. Mura, L.; Kljucnikov, A. Small Businesses in Rural Tourism and Agrotourism: Study from Slovakia. Econ. Sociol. 2018, 11, 286-300. [CrossRef]

10. Bervidova, L. Labour productivity as a factor of sustainable economic development of the CR agriculture. Agric. Econ. 2002, 48, 55-59. [CrossRef] 
11. International Institute for Sustainable Development. Available online: https://www.iisd.org/about-iisd/sustainable-development (accessed on 5 September 2020).

12. Serrano, L.; Sianes, A.; Ariza-Montes, A. Using Bibliometric Methods to Shed Light on the Concept of Sustainable Tourism. Sustainability 2019, 11, 6964. [CrossRef]

13. Escoto, B.; Estela, B.; Boza, P.; Feito, M.; Duniesky, M. Sustainable Tourism: A Competitiveness Strategy Perspective in Baja California. Sustainability 2019, 11, 6934. [CrossRef]

14. Brohm, K.A.; Klein, S. The Concept of Climate Smart Agriculture-A Classification in Sustainable Theories. Int. J. Qual. Res. 2020, 14, 291-302. [CrossRef]

15. Bock, A.; Sparks, T.H.; Estrella, N.; Menzel, A. Climate-Induced Changes in Grapevine Yield and Must Sugar Content in Franconia (Germany) between 1805 and 2010. PLoS ONE 2013, 8, e69015. [CrossRef] [PubMed]

16. Pejml, K. Příspěvek ke znalosti klimatu v Čechách v 16. až 18 stol. Meteorol. Zpr. 1974, 27, 90-95.

17. Dressler, M. The German Wine Market: A Comprehensive Strategic and Economic Analysis. Beverages 2018, 4, 29. [CrossRef]

18. Van Leeuwen, C.; Darriet, P. The Impact of Climate Change on Viticulture and Wine Quality. J. Wine Econ. 2016, 11, 150-167. [CrossRef]

19. Koch, B.; Oehl, F. Climate Change Favors Grapevine Production in Temperate Zones. Agric. Sci. 2018, 9, 247-263. [CrossRef]

20. Kebede, A.S.; Dunford, R.; Mokrech, M.; Auds-Ley, E.; Harrison, P.A.; Holman, I.P.; Nicholls, R.J.; Rickebusch, S.; Rounsevell, M.D.A.; Sabate, S.; et al. Direct and indirect impacts of climate and socio-economic change in Europe: A sensitivity analysis for key land- and water-based sectors. Clim. Chang. 2015, 128, 261-277. [CrossRef]

21. Macku, J. Climatic characteristics of forest vegetation zones of the Czech Republic. J. Landsc. Ecol. 2014, 7, 239-262. [CrossRef]

22. Trnka, M.; Brazdil, R.; Dubrovsky, M.; Semeradova, D.; Stepanek, P.; Dobrovolny, P.; Mozny, M.; Eitzinger, J.; Malek, J.; Formayer, H.; et al. A 200-year climate record in Central Europe: Implications for agriculture. Agron. Sustain. Dev. 2011, 31, 631-641. [CrossRef]

23. Brazdil, R. Climatic fluctuation in the Czech Lands during the last millennium. GeoJournal 1994, 32, 199-205. [CrossRef]

24. Mosedale, J.R.; Abernethy, K.E.; Smart, R.E.; Wilson, R.J.; Maclean, I.M.D. Climate change impacts and adaptive strategies: Lessons from the grapevine. Glob. Change Biol. 2016, 22, 3814-3828. [CrossRef] [PubMed]

25. Hannah, L.; Roehrdanz, P.R.; Ikegami, M.; Shepard, A.V.; Shaw, M.R.; Tabor, G.; Zhi, L.; Marquet, P.A.; Hijmans, R.J. Climate change, wine, and conservation. Proc. Natl. Acad. Sci. USA 2013, 110, 6907-6912. [CrossRef] [PubMed]

26. Duchêne, E.; Huard, F.; Dumas, V.; Schneider, C.; Merdinoglu, D. The challenge of adapting grapevine varieties to climate change. Clim. Res. 2010, 41, 193-204. [CrossRef]

27. Schultz, H.R. Global Climate Change, Sustainability, and Some Challenges for Grape and Wine Production. J. Wine Econ. 2016, 11, 181-200. [CrossRef]

28. 2019 Statistical Report on World Vitiviniculture International-OIV: International Organisation of Vine and Wine. Available online: http:/ / www.oiv.int/public/medias/6782/oiv-2019-statistical-report-on-world-vitiviniculture.pdf (accessed on 23 May 2020).

29. Lage im Weltweiten Weinbausektor 2019-OIV: International Organisation of Vine and Wine. Available online: http://www.oiv. int/js/lib/pdfjs/web/viewer.html?file=/public/medias/7301/de-lage-im-weltweitenweinbausektor-2019.pdf (accessed on 6 July 2020).

30. Wine Production: A Global Overview-WSET: Wine \& Spirit Education Trust. Available online: https://www.wsetglobal.com/ media/3009/wine-production-a-global-overview.pdf (accessed on 30 November 2020).

31. Banks, G.; Overton, J. Old World, New World, Third World? Reconceptualising the Worlds of Wine. J. Wine Res. 2010, 21, 57-75. [CrossRef]

32. Hendl, J.; Remr, J. Metody Výzkumu a Evaluace, 1st ed.; Portál: Praha, Czech Republic, 2017.

33. Hendl, J. Kvalitationí Výzkum: Základní Metody a Aplikace, 1st ed.; Portál: Praha, Czech Republic, 2005.

34. Ministry of Agriculture Czech Republic: Situační a Výhledové Zprávy Réva vinná a víno 2000-2019. Available online: http:/ / eagri.cz/public/web/mze/zatrideni-vina/reva-vinna-a-vino/situacni-a-vyhledove-zpravy/?pos=0 (accessed on 25 June 2020).

35. Sedlo, J.; Půček, M. Sklizeň Moštovacích Hroznů v ČR v roce 2019_Association of Winemakers of the Czech Republic. Available online: https: / / www.svcr.cz/files/2020/03/5687c480b1460aeaeac21bd074c8f990.pdf (accessed on 25 June 2020).

36. Eckstein, P.P. Repetitorium Statistik: Deskriptive Statistik—Stochastik—Induktive Statistik, 8th ed.; Aktualisierte und Erweiterte Auflage; Springer Gabler: Wiesbaden, Germany, 2014.

37. Barton, B.; Peat, J. Medical Statistics: A Guide to SPSS, Data Analysis and Critical Appraisal, 2nd ed.; John Willey \& Sons Inc.: New York, NY, USA, 2014.

38. Breusch, T.S.; Pagan, A.R. A Simple Test for Heteroscedasticity and Random Coefficient Variation. Econometrica 1979, 47, 1287-1294. [CrossRef]

39. Tomsik, P.; Zufan, P. Analýza atraktivity odvětví vinařství v České republice. Acta Univ. Agric. Silvic. Mendel. Brunesis 2004, LII, 135-142.

40. Svobodova, I.; Veznik, A.; Kral, M. Viticulture in the Czech Republic: Some Spatio-Temporal Trends. Morav. Geogr. Rep. 2014, 22, 2-14. [CrossRef]

41. Tomsik, P.; Sedlo, J. Adaptation of the Czech viniculture to the conditions of the European Union: Structure and Suitability in a Variable and Changing Climate. Agric. Econ. 2006, 51, 509-520. 
42. Interaktivní mapa Vinařských Oblastí a Podoblastí ČR. Available online: http://eagri.cz/public/web/ukzuz/portal/trvalekultury/registrace/registrace-vinic/interaktivni-mapa-vinarskych-oblasti-a.html (accessed on 10 September 2020).

43. Ragasová, L.; Kopta, T.; Winkler, J.; Pokluda, R. The Current Stage of Greening Vegetation in Selected Wine-Regions of South Moravian Region (Czech Republic). Agronomy 2019, 9, 541. [CrossRef]

44. Hejmalova, H.; Sperkova, R. Assessment of attractiveness of the wine-production industry in the Czech Republic. Acta Univ. Agric. Silvic. Mendel. Brun. 2011, 59, 89-98. [CrossRef]

45. Ministry of Agriculture Czech Republic: Registrace Vinic. Available online: eagri.cz/public/web/ukzuz/portal/trvale-kultury/ registrace/registrace-vinic (accessed on 15 July 2020).

46. Location of the Czech Republic. Available online: https://www.cia.gov/library/publications/the-world-factbook/attachments/ locator-maps/EZ-locator-map.jpg (accessed on 28 November 2020).

47. Czech Statistical Office Spotřeba Potravin-2017. Available online: https://www.czso.cz/csu/czso/spotreba-potravin-2017 (accessed on 6 July 2020).

48. Czech Statistical Office Spotřeba Potravin-2018. Available online: https://www.czso.cz/csu/czso/spotreba-potravin-2018 (accessed on 9 July 2020).

49. Zhang, Z.; Zou, L.; Ren, C.; Ren, F.; Wang, Y.; Fan, P.; Li, S.; Liang, Z. VvSWEET10 Mediates Sugar Accumulation in Grapes. Genes 2019, 10, 255. [CrossRef] [PubMed]

50. Tomsik, P.; Stojanova, H.; Sedlo, J.; Vajcnerova, I. Factors of profitability of the grapes production. Agric. Econ. 2016, 62, $292-297$. [CrossRef]

51. Leolini, L.; Moriondo, M.; Romboli, Y.; Gardiman, M.; Costafreda-Aumedes, S.; Costafreda-Aumedes, S.; Bindi, M.; Granchi, L.; Brilli, L. Modelling sugar and acid content in Sangiovese grapes under future climates: An Italian case study. Clim. Res. 2019, 78, 211-224. [CrossRef]

52. Petrie, P.R.; Teng, B.; Smith, P.A.; Bindon, K.A. Sugar reduction: Managing high Baume juice using dilution. Wine Vitic. J. 2019, 34, 36-37.

53. Jackson, R.S. Wine Science: Principles and Applications, 5th ed.; Springer: New York, NY, USA, 2010.

54. Margalit, Y. Concepts in Wine Chemistry, 3rd ed.; Wine Appreciation Guild: San Francisco, CA, USA, 2016.

55. Act No. 321/2004 Coll. on Viticulture and Wine-Growing in the Czech Republic. Available online: http://eagri.cz/public/web/ vinarsky-zakon/ (accessed on 28 August 2020).

56. Pavlousek, P. Výroba vína u Malovinař̀i, 2nd ed.; Grada: Praha, Czech Republic, 2010.

57. Pavlousek, P. Výroba vína u Malovinařů, 1st ed.; Grada: Praha, Czech Republic, 2006.

58. Zdrahal, I.; Becvarova, V.; Babackova, J. Development of New Organization Forms in Viticulture and Wine Industry in the Czech Republic-The Segment of Wines with Original Certification. In Proceedings of the International Scientific Conference (Inproforum 2017), České Budějovice, Czech Republic, 9-10 November 2017; University of South Bohemia: České Budějovice, Czech Republic, 2017; pp. 120-125.

59. Association of Winemakers of the Czech Republic. Available online: https://www.svcr.cz/cs/na-ceste-za-apelacnim-systememceske-republiky (accessed on 25 June 2020).

60. Gerling, C. Residual Sugar: Chemistry and Perception. Cornel University: College of Agriculture and Life Sciences. Available online: https: / cpb-us-e1.wpmucdn.com/blogs.cornell.edu/dist/0/7265/files/2016/11/ResidualSugar-vn6hqe.pdf (accessed on 20 June 2020).

61. Puckette, M.; Hammack, M. Wine Folly: Magnum Edition: The Master Guide; Penguin Random House: New York, NY, USA, 2018.

62. OIV—Produktdefinition-Kartei des Kodex. Available online: http://www.oiv.int/de/normen-und-technische-dokumente/ produktdefinitionen-und-etikettierung/produktdefinition-kartei-des-kodex (accessed on 28 August 2020).

63. Blanco-Ward, D.; García Queijeiro, G.; Jones, G.V. Spatial climate variability and viticulture in the Miño River Valley of Spain. Vitis 2007, 46, 63-70.

64. Schultz, H.R.; Hoppmann, D.; Hoffman, M. Der Einfluss klimatischer Veränderungen auf die phänologische Entwicklung der Rebe, die Sorteneignung sowie Mostgewicht und Säurestruktur der Trauben. Available online: https://www.hlnug.de/ fileadmin/dokumente/klima/inklim/endberichte/weinbau.pdf (accessed on 13 June 2020).

65. Huglin, P. Biologie et Écologie de la Vigne; Lavoisier: Paris, France, 1986.

66. Zorer, R.; Rocchini, D.; Delucchi, L.; Zottele, F.; Meggio, F.; Neteler, M. Use of multi-annual MODIS Land Surface Temperature data for the characterization of the heat requirements for grapevine varieties. In Proceedings of the 2011 6th International Workshop on the Analysis of Multi-Temporal Remote Sensing Images (Multi-Temp), Trento, Italy, 12-14 July 2011 ; pp. $225-228$.

67. Amerine, M.A.; Winkler, A.J. Composition and Quality of Musts and Wines of California Grapes. Hilgardia 1944, 15, 493-675. [CrossRef]

68. Czech Hydrometeorogical Institute. Available online: http:/ / portal.chmi.cz/historicka-data/pocasi/denni-data/Denni-datadle-z.-123-1998-Sb (accessed on 27 August 2020).

69. Machar, I.; Vlckova, V.; Bucek, A.; Vrublova, K.; Filippovova, J.; Brus, J. Environmental Modelling of Climate Change Impact on Grapevines: Case Study from the Czech Republic. Pol. J. Environ. Stud. 2017, 26, 1927-1933. [CrossRef]

70. Olesen, J.E.; Bindi, M. Consequences of climate change for european agricultural productivity, land use and policy. Eur. J. Agron. 2002, 16, 239-262. [CrossRef] 
71. Carroquino, J.; Garcia-Casarejos, N.; Gargallo, P. Classification of Spanish wineries according to their adoption of measures against climate change. J. Clean. Prod. 2020, 244, 142-155. [CrossRef]

72. Blanco-Ward, D.; Monteiro, A.; Lopes, M.; Borrego, C.; Silveira, C.; Viceto, C.; Rocha, A.; Ribeiro, A.; Andrade, J.; Feliciano, M.; et al. Climate change impact on a wine-producing region using a dynamical downscaling approach: Climate parameters, bioclimatic indices and extreme indices. Int. J. Climatol. 2019, 39, 5741-5760. [CrossRef]

73. Mozell, M.R.; Thach, L. The impact of climate change on the global wine industry. Wine Econ. Policy 2014, 3, 81-89. [CrossRef]

74. Jones, G.V.; Hellman, E. Site Assessment and Oregon Wine-growing Regions. Or. Vitic. 2003, 5, 44-50, 51-69.

75. Jones, G.V.; White, M.A.; Cooper, O.R.; Storchmann, K. Climate change and global wine quality. Clim. Change 2005, 73, 319-343. [CrossRef]

76. Keller, M. Managing grapevines to optimise fruit development in a challenging environment: A climate change primer for viticulturists. Aust. J. Grape Wine Res. 2010, 16, 56-69. [CrossRef]

77. Deckers, D. Wein: Geschichte und Genuss, 1st ed.; Verlag C. H. Beck: München, Deutschland, 2017.

78. This, P.; Lacombe, T.; Thomas, M. Historical origins and genetic diversity of wine grapes. Trends Genet. 2006, 22, 511-519. [CrossRef]

79. Wolkovich, E.M.; García de Cortázar-Atauri, I.; Morales-Castilla, I.; Nicholas, K.A.; Lacombe, T. From Pinot to Xinomavro in the world's future wine-growing regions. Nat. Clim. Chang. 2018, 8, 29-37. [CrossRef]

80. Bigard, A.; Berhe, D.T.; Maoddi, E.; Sire, Y.; Boursiquot, J.-M.; Ojeda, H.; Péros, J.-P.; Doligez, A.; Romieu, C.; Torregrosa, L. Vitis vinifera L. Fruit Diversity to Breed Varieties Anticipating Climate Changes. Front. Plant Sci. 2018, 9. Available online: https: / / www.frontiersin.org/articles/10.3389/fpls.2018.00455/full (accessed on 12 June 2020). [CrossRef]

81. Neethling, E.; Petitjean, T.; Quénol, H.; Barbeau, G. Assessing local climate vulnerability and winegrowers' adaptive processes in the context of climate change. Mitig. Adapt. Strateg. Glob. Change 2017, 22, 777-803. [CrossRef]

82. Jones, G.V.; Reid, R.; Vilks, A. Climate, grapes, and wine: Structure and suitability in a variable and changing climate. Geogr. Wine 2012, 16, 109-133.

83. Mozny, M.; Brazdil, R.; Dobrovolny, P.; Trnka, M. April-August temperatures in the Czech Lands, 1499-2015, reconstructed from grape-harvest dates. Clim. Past 2016, 12, 1421-1434. [CrossRef]

84. Santillan, D.; Iglesias, A.; La Jeunesse, I.; Garrote, L.; Sotes, V. Vineyards in transition: A global assessment of the adaptation needs of grape producing regions under climate change. Sci. Total Environ. 2019, 657, 839-852. [CrossRef] [PubMed]

85. Warner, K.D. The quality of sustainability: Agroecological partnerships and the geographical branding of California winegrapes. J. Rural Stud. 2007, 23, 142-155. [CrossRef]

86. Thiollet-Scholtus, M.; Bockstaller, C. Using indicators to assess the environmental impacts of wine growing activity: The INDIGO (R) method. Eur. J. Agron. 2015, 62, 13-25. [CrossRef]

87. ProWein Business Report 2019. Available online: https://www.prowein.com/en/For_Press/Press_material/Press_Releases/ Current_ProWein_Business_Report_2019_is_available (accessed on 5 October 2020).

88. Charters, S.; Pettigrew, S. The dimensions of wine quality. Food Qual. Prefer. 2007, 18, 997-1007. [CrossRef]

89. Stone, H.; Bleibaum, R.; Thomas, H. Sensory Evaluation Practices, 4th ed.; Elsevier Science: Burlington, NJ, USA, 2012.

90. Brand, J.; Panzeri, V.; Buica, A. Wine Quality Drivers: A Case Study on South African Chenin Blanc and Pinotage Wines. Foods 2020, 9, 805. [CrossRef]

91. De Orduna, R.M. Climate change associated effects on grape and wine quality and production. Food Res. Int. 2010, 43, 1844-1855. [CrossRef]

92. Shanmuganathan, S.; Whalley, J.; Perez-Kuroki, A. Climate effects on grape production and quality at Kumeu, New Zealand. In Proceedings of the 20th International Congress on Modelling and Simulation (MODSIM2013), Adelaide, Australia, 1-6 December 2013; Piantadosi, J., Anderssen, R.S., Boland, J., Eds.; Auckland Univ. Technol.: Auckland, New Zealand, 2013 ; pp. 817-823.

93. Lorenzo, M.N.; Taboada, J.J.; Lorenzo, J.F.; Ramos, A.M. Influence of climate on grape production and wine quality in the Rias Baixas, north-western Spain. Reg. Environ. Chang. 2013, 13, 887-896. [CrossRef]

94. Beauchet, S.; Cariou, V.; Renaud-Gentie, C.; Meunier, M.; Siret, R.; Thiollet-Scholtus, M.; Jourjon, F. Modeling grape quality by multivariate analysis of viticulture practices, soil and climate. Oeno ONE 2010, 54, 601-622.

95. Irimia, L.M.; Patriche, C.V.; Bucur, G.M.; Quenol, H.; Cotea, V.V. Spatial Distribution of Grapes Sugar Content and its Correlations with Climate Characteristics and Climate Suitability in the Husi (Romania) Wine Growing Region. Not. Bot. Horti Agrobot. Cluj-Napoca 2015, 1, 250-258. [CrossRef]

96. Hewer, M.J.; Gough, W.A. Assessing the impact of projected climate change on the future of grape growth and wine production in the Niagara Peninsula (Canada). J. Wine Res. 2020, 31, 6-34. [CrossRef]

97. Van Leeuwen, C. Terroir: The effect of the physical environment on vine growth, grape ripening and wine sensory attributes. In Managing Wine Quality. Viticulture and Wine Quality; Reynolds, A.G., Ed.; Woodhead Publishing: Cambridge, UK, 2010; pp. 273-315.

98. Macedo, A.; Gouveia, S.; Rebelo, J. Does Wine Quality Have a Bearing on Exports? AGRIS Online Pap. Econ. Inform. 2019, 11, 49-59. [CrossRef] 